\title{
CLINICAL AND BIO-CHEMICAL PARAMETERS OF NEPHROTIC SYNDROME IN CHILDREN AND FACTORS INFLUENCING REMISSION
}

K. M. Naicker ${ }^{1}$, V. V. Bhaskar Rao², K. Adi Reddy³, Solomon Saawan P4, Krishna Kumari Agarwal5, K. Veera Bhadrarao ${ }^{6}$

\section{HOW TO CITE THIS ARTICLE:}

K. M. Naicker, V. V. Bhaskar Rao, K. Adi Reddy, Solomon Saawan P, Krishna Kumari Agarwal, K. Veera Bhadrarao. "Clinical and Bio-Chemical Parameters of Nephrotic Syndrome in Children and Factors Influencing Remission". Journal of Evolution of Medical and Dental Sciences 2015; Vol. 4, Issue 68, August 24; Page: 11857-11864, DOI: $10.14260 /$ jemds/2015/1709

\begin{abstract}
Nephrotic syndrome is primarily pediatric disorder and is 15 times more common in children than adults. ${ }^{1}$ It is a clinical entity characterized by massive proteinuria (albumin) Hypoalbuminemia, edema and hyperlipidemia). In about $95 \%$ of cases of Nephrotic syndrome in children there is a primary glomerular abnormality, ${ }^{2}$ the aim of the study is to assess the clinicobiochemical parameters of Nephrotic syndrome in children. To study the relationship, if any, between the serum proteins and cholesterol levels and their correlation with therapeutic response.
\end{abstract}

KEYWORDS: Nephrotic syndrome, Naicker, Hypoproteinemia, Hypercholestremia.

\section{INTRODUCTION:}

Study Method: The study includes children less than 14 years of age coming to Pediatric Outpatient and Inpatient Department, Govt. General Hospital, Kakinada from June 2014 to June 2015. This is a Prevalence study. The study includes 50 children.

\section{RESULTS:}

- Most of the children were in the age group between 2-8 yrs $^{3}$. (37 cases 74\%). Average age of presentation is $6.7 \mathrm{yrs}$. There is a male preponderance of $\mathrm{M}: \mathrm{F}=1.7: 1.4$

- Duration of illness (edema) at the time of presentation was 5 days and average duration of illness is 14.7 days.

- All cases were brought with generalized edema starting around eyes which spreads gradually to whole body. Scrotal edema was seen in 18 out of 32 males (56.25\%). Ascites was found in 45 cases (90\%). Oliguria was found in all cases (100\%). ${ }^{5}$ Pleural effusion is found in 15 cases (30\%).

- 24 hour urinary protein estimation in this study ranges from $125 \mathrm{mg}$ to $2.85 \mathrm{gm}$. Hypoprotenemia (Serum albumin $<3.0 \mathrm{gm}$ ) is seen in 44 cases $(88 \%)$ and total serum proteins range from $2.7 \mathrm{gm}$. to $6.6 \mathrm{gm}$. Serum cholesterols levels above the level of $250 \mathrm{mg} / \mathrm{dl}$ was found in 47 cases $(94 \%)$.

- 35 cases out of 50 showed anemia.

- Blood urea is elevated in 3 cases without concomitant rise of serum creatinine (6\%) in the study, Suggestive of Hypovolemia. ${ }^{6}$

- It is noted that with increasing serum albumin levels, the time taken for remission is decreased. So an inverse relationship is found between serum albumin levels and time taken for remission. It was also observed that lower the cholesterol levels, quicker the response to steroids. ${ }^{7}$

CONCLUSION: There is male preponderance in childhood Nephrotic syndrome. 2-8 yrs. is the commonest age group effected in this study. Preceding illness is recorded in $70 \%$ of cases, URI being 


\section{ORIGINAL ARTICLE}

the commonest. ${ }^{8}$ almost all patients presented with insidious onset of edema, starting as facial puffiness and gradually spread to body. The response to steroid treatment was delayed in patients with marked reduction of serum albumin levels and marked elevation of serum cholesterol levels. Complications for steroid treatment are mild and disappeared after gradual withdrawal. ${ }^{9}$

\section{MATERIALS AND METHODS:}

Source of Data: Children presenting with Anasarca (Edema) up to 14 yrs of age in Pediatrics Outpatient and Inpatient departments in Government General Hospital, Rangaraya Medical College, Kakinada from June 2014 to June 2015 were the source of cases for study.

\section{SAMPLING METHODS:}

Inclusion Criteria: The study includes children below 14years of age with complaints of Anasarca (edema), with proteinuria, Hypoprotenemia and Hypercholestremia on biochemical examination, taking proteinuria and edema as essential features.

Exclusion Criteria: The other causes of edema like CHF, Hepatic causes are excluded in this study. Patients presenting with macroscopic hematuria and hypertension were also excluded from the study.

Method of Collection of Data: Data was collected with detailed case taking in all children included in the study. Detailed history was taken to denote site of edema, onset and mode of spread, diurnal variation, micturition, oliguria, burning sensation on micturition, history of flank or loin pain.

Obvious precipitating factors like upper respiratory tract infections, pyoderma, sore throat, exanthematous fever, history of using nephrotoxic drugs, snake bites, bee stings, history of jaundice [HBV], chicken pox, any history of use of contrast media for investigations, fever with chills and rigors [malaria], features suggestive of thromboembolic phenomenon, systemic sepsis, renal failure, abdominal pain, history of altered bowel habit or cellulitis, history of or contact with tuberculosis were noted. ${ }^{10}$

Investigations done were complete urine examination, 24hour urinary protein estimation, urine culture and sensitivity, urine spot protein/creatinine ratio. Complete blood picture, renal function tests, liver function tests, serum cholesterol, serum electrolytes, serum fibrinogen levels, hemogram with peripheral smear, testing for HBsAg, complement levels, ANA/DNA antibodies, plain X-rays of chest, ultrasonogram of abdomen and chest, mantoux test.

Treatment: After admission necessary investigations were done and child was screened for any infective focus especially urinary tract infections by urinary microscopy, urine culture and sensitivity and tuberculosis by $\mathrm{x}$-ray chest and Mantoux test. All the patients were initially started on prednisolone $2 \mathrm{mg} / \mathrm{kg} /$ day in divided doses up to maximum $60 \mathrm{mg} /$ day ${ }^{11}$.

For initial cases prednisolone is given at a dose of $2 \mathrm{mg} / \mathrm{kg} /$ day for 6 weeks followed by 1.5 $\mathrm{mg} / \mathrm{kg} /$ day on alternate days for another 6 weeks ${ }^{12}$. Therapy is then stopped. The alternate day medication is administered as a single morning dose.

Relapses cases were treated at a dose of $2 \mathrm{mg} / \mathrm{kg} /$ day in 2 divided doses for 2 weeks, followed by alternate day treatment given in a dose of $1.5 \mathrm{mg} / \mathrm{kg} /$ day for next 4 weeks ${ }^{13}$. Renal biopsy was done outside for 1 case of steroid dependent Nephrotic syndrome and Biopsy revealed MCNS.14,15 


\section{ORIGINAL ARTICLE}

For 2 cases of steroid dependence, Levamisole in a dose of $2 \mathrm{mg} / \mathrm{kg} /$ day on alternate days along with alternate day low dose prednisolone in a dose of $0.5 \mathrm{mg} / \mathrm{kg} /$ day was given ${ }^{16}$. Urine is frequently examined for protein to detect remission. All the patients were given a high protein, low fat diet \& low cholesterol diet. Diuretics (Inj. Frusemide) are given in some cases in which Edema is severe and causing respiratory distress ${ }^{17}$ but rapid fluid loss is never attempted.

Cases were followed up even after discharge from hospital. On follow up all patients were subjected to serum cholesterol and serum protein estimation [20-30days after discharge].

RESULTS: Age: The youngest child present in this study was 1.9 yrs. old male and oldest was 12 yr. old child. Most of the children were in the age group between 2-8 yrs. (37 cases 74\%). Average age of presentation is $6.7 \mathrm{yrs}$.

\begin{tabular}{|c|c|c|}
\hline Age in years & No. of cases & Percentage \\
\hline $2-5$ & 19 & $38 \%$ \\
\hline $6-8$ & 18 & $36 \%$ \\
\hline $9-12$ & 13 & $26 \%$ \\
\hline
\end{tabular}

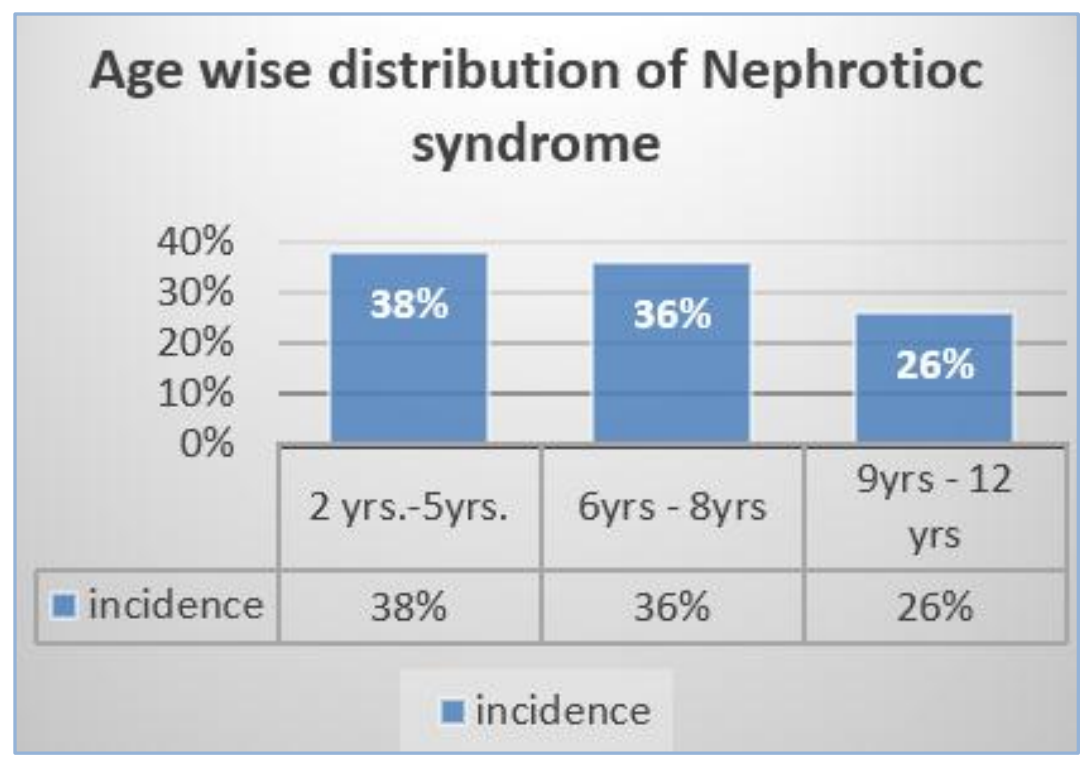

Sex: There is a Male Preponderance of M: F = 1.7:1.

\begin{tabular}{|c|c|c|}
\hline Sex & No. of Cases & Percentage \\
\hline Male & 32 & $64 \%$ \\
\hline Female & 18 & $36 \%$ \\
\hline
\end{tabular}




\section{ORIGINAL ARTICLE}

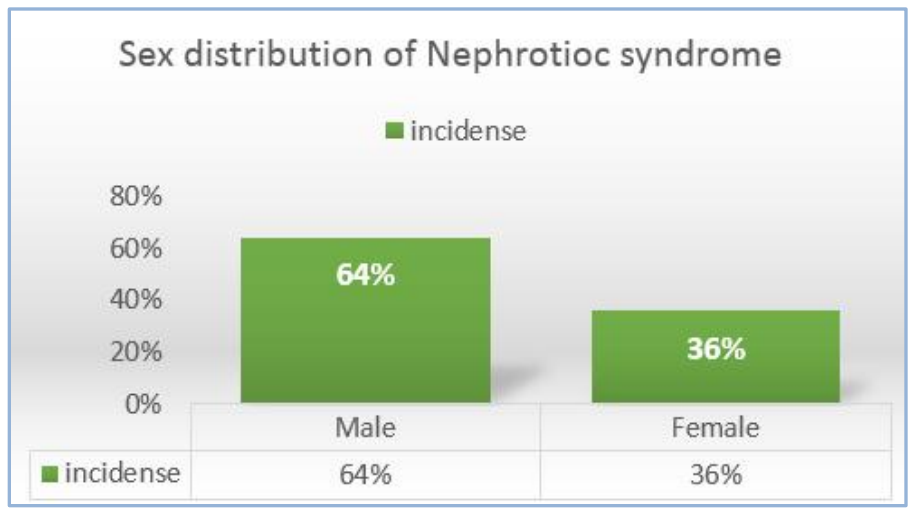

Duration of Illness: Duration of illness (Edema) at the time of presentation was 5 days and maximum is 30 days with average duration of illness is 14.7 days.

Type of Presentation: No of initial cases were 16(32\%) and no of relapse cases were 34(68\%). Some of the initial cases were treated earlier by native medication, Ayurveda, Homeopathy without any improvement. The relapses were treated earlier by our hospital or outside pediatricians.

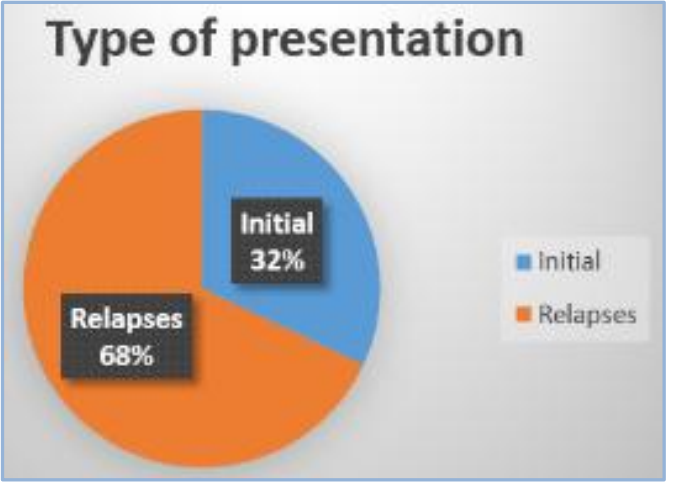

Mode of Presentation: All cases were brought with generalized edema starting around eyes which spreads gradually to whole body. Scrotal edema was seen in 18 out of 32 males $(56.25 \%)^{18}$. Ascites was found in 45 cases (90\%). Oliguria was found in all cases (100\%). Pleural effusion is found in 15 cases (30\%). Signs of respiratory distress was seen in 5 cases (10\%) due to tense ascites.

\section{Laboratory Data:}

\begin{tabular}{|l|c|c|}
\hline \multicolumn{1}{|c|}{ Investigation } & No. of Cases & Percentage \\
\hline 1.Proteinuria & 48 & $96 \%$ \\
\hline 2.Hypoprotenemia & 44 & $88 \%$ \\
\hline 3.Hypercholestremia & 47 & $94 \%$ \\
\hline 4.Elevated Blood urea & 3 & $6 \%$ \\
\hline 5.Anemia & 35 & $70 \%$ \\
\hline
\end{tabular}




\section{ORIGINAL ARTICLE}

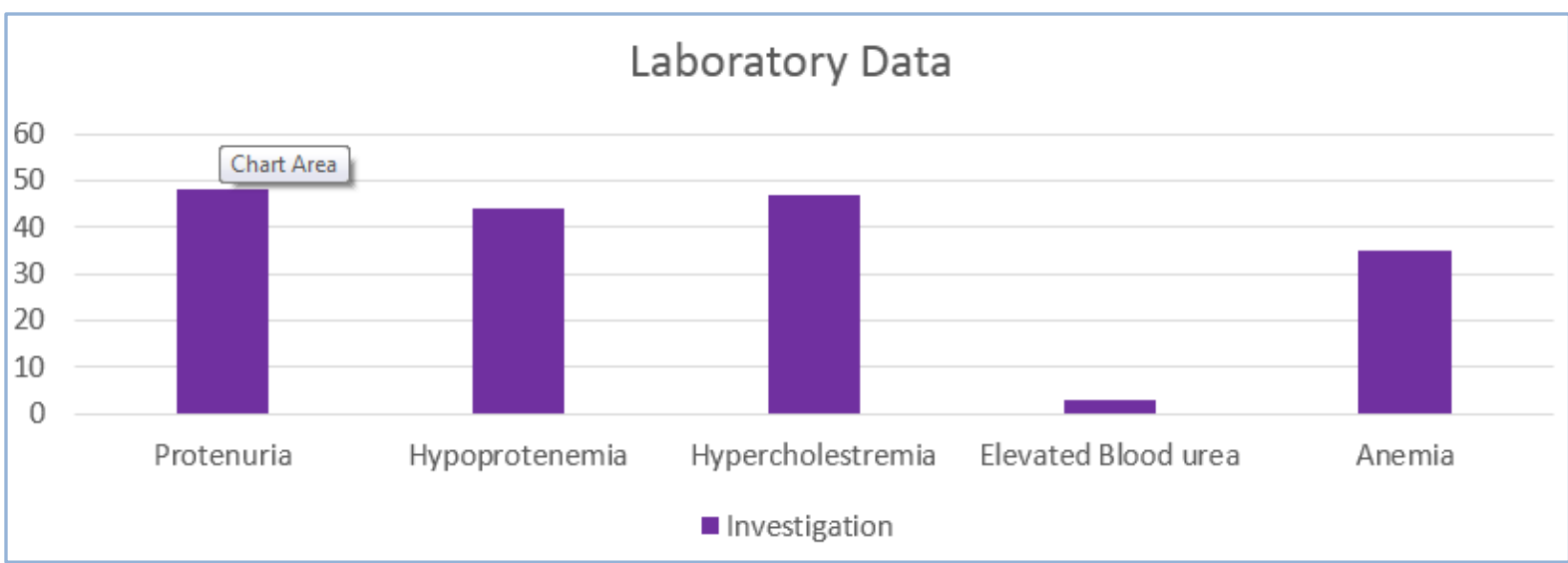

24 hour urinary protein estimation in this study ranges from $125 \mathrm{mg}$. to 2.85gm. Hypoprotenemia (Serum albumin $<3.0 \mathrm{gm}$ ) is seen in 44 cases $(88 \%)$ and total serum proteins range from 2.7 gm. to $6.6 \mathrm{gm}$. Serum cholesterols levels above the level of $250 \mathrm{mg} / \mathrm{dl}$ was found in 47 cases (94\%) minimum value is $172 \mathrm{mg} / \mathrm{dl}$ and maximum is $800 \mathrm{mg} / \mathrm{dl}$.

35 cases out of 50 showed anemia. (According to age \& sex standards of IAP guidelines)

Blood urea is elevated in 3 cases $(6 \%)$ without concomitant rise of serum creatinine in the study, Suggestive of Hypovolemia.

Urinary tract infection is proved in one case (2\%) by culture and was treated with appropriate antibiotics based on culture and sensitivity report. TB is diagnosed in 2 cases (4\%) and Anti tuberculous therapy was started before initiation of steroid therapy. Cellulitis of lower limb was found in 2 cases (4\%) and was treated with IV antibiotics before starting steroid therapy ${ }^{19}$.

Steroid Toxicity: Complications associated with steroids were noted only after 4-6 weeks of steroid therapy. It was observed in 3 cases $(6 \%)$ in the form of Cushingoid facies and subsided after cessation of steroid therapy ${ }^{20}$.

\section{Biochemical Observations with Correlation to Clinical Status and Remission:}

1. Serum Albumin Vs. Time taken for Remission: It is noted that with increasing serum albumin levels, the time taken for remission is decreased. So an inverse relationship is found between serum albumin levels and time taken for remission ${ }^{21 .}$

\begin{tabular}{|c|c|c|}
\hline $\begin{array}{c}\text { Serum Albumin } \\
\mathbf{m g} / \mathbf{d l}\end{array}$ & $\begin{array}{c}\text { No. of } \\
\text { Cases }\end{array}$ & $\begin{array}{c}\text { Average Time Taken } \\
\text { for Remission in Days }\end{array}$ \\
\hline $1.0-1.5$ & $2(4 \%)$ & 15 \\
\hline $1.6-2.0$ & $16(32 \%)$ & 10 \\
\hline $2.1-2.5$ & $12(24 \%)$ & 9 \\
\hline $2.6-3.0$ & $11(22 \%)$ & 7.7 \\
\hline $3.1-3.5$ & $7(14 \%)$ & 5.5 \\
\hline $3.6-4.0$ & $2(4 \%)$ & 4.5 \\
\hline
\end{tabular}




\section{ORIGINAL ARTICLE}

2. Serum Cholesterol vs. Time taken for Remission: It was also observed that lower the cholesterol levels, quicker the response to steroids.

\begin{tabular}{|c|c|c|}
\hline $\begin{array}{c}\text { Serum Cholesterol } \\
\mathbf{m g} / \mathbf{d l}\end{array}$ & $\begin{array}{c}\text { No. of } \\
\text { Cases }\end{array}$ & $\begin{array}{c}\text { Average Time taken } \\
\text { for Remission in Days }\end{array}$ \\
\hline $150-250$ & $3(6 \%)$ & 3.3 \\
\hline $250-350$ & $11(22 \%)$ & 5.7 \\
\hline $350-450$ & $12(24 \%)$ & 7.8 \\
\hline $450-550$ & $16(32 \%)$ & 9.6 \\
\hline $550-650$ & $6(12 \%)$ & 10.3 \\
\hline $650-750$ & $2(4 \%)$ & 14.5 \\
\hline $750-850$ & $1(2 \%)$ & 18 \\
\hline
\end{tabular}
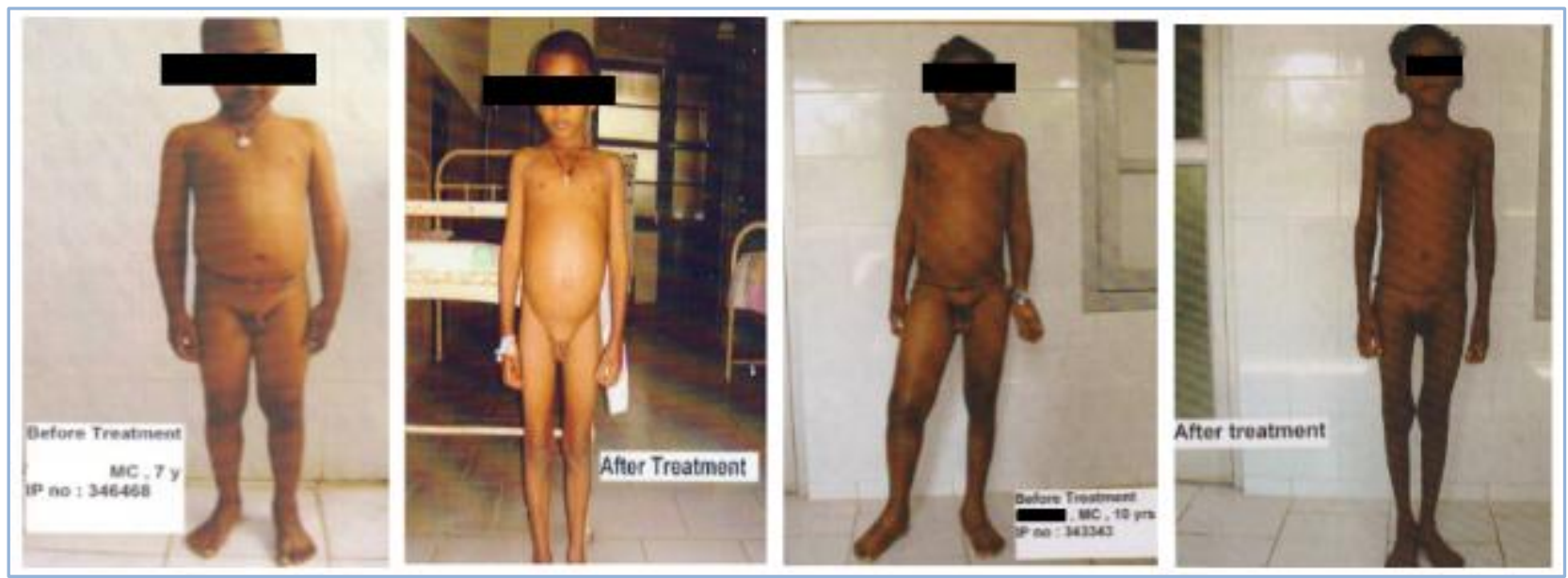

DISCUSSION: In this study of 50 cases majority belong to age group 2-8 yrs. with a male preponderance. Sometimes the initial episode and majority of relapses appeared to be precipitated by various infections, Upper respiratory tract infections (70\%) being the commonest. Anemia was found in significant number of cases i.e. 35 cases (70\%) and found to have iron deficiency anemia on peripheral smear, treated and responded well with oral iron therapy ${ }^{22}$. Cases with tuberculosis showed initial delayed response to steroid therapy. ${ }^{23}$ Elevated blood urea levels were found in 3 cases (6\%) with rise in serum creatinine levels probably due to pre renal azotemia due to hypovolemia. The serum proteins and serum cholesterol analysis and their relation to time taken for remission may be helpful in indicating the prognosis. All cases responded to steroids within 3 weeks with average time taken for remission around 10 days.

\section{CONCLUSION:}

- $\quad$ There is male preponderance in childhood Nephrotic syndrome 24 .

- $\quad 2-8$ yrs. is the commonest age group effected in this study.

- Preceding illness is recorded in $70 \%$ of cases, URI being the commonest.

- Almost all patients presented with insidious onset of edema, starting as facial puffiness and gradually spread to body. 
- The response to steroid treatment was delayed in patients with marked reduction of serum albumin levels.

- The onset of remission is delayed in patients with marked elevation of serum cholesterol levels.

- Inverse correlation was observed between levels of serum albumin and serum cholesterol levels.

- Complications for steroid treatment are mild and disappeared after gradual withdrawal.

\section{REFERENCES:}

1. Nelson Text book of pediatrics $-19^{\text {th }}$ edition. 2011; 23 chapter p6346 - 6421.

2. Abraham. M .Rudolph - Textbook of pediatrics 21st edition- 21chapter p1632 -67.

3. Srivastava - clinical profile of Nephrotic Syndrome in children Arch. Dis. Child 1978, RN Srivastava \& Aravind Bagga - Pediatric Nephology- $5^{\text {th }}$ edition 2011; 195 -234.

4. Tamilrasi - Clinical Pediatric Nephology- 1st edition 2008; 441 -461.

5. Furfur text book of pediatrics - 3rd Edition 2007; $311-341$.

6. ISKDC. Primary nephrotic Syndrome in Children Kidney Int.1981, 20765.

7. Viziri ND. Molecular mechanisms of lipid disorders in Nephrotic syndrome. Kidney Int 2003; 63:1964 -76.

8. OSKI's Pediatrics - 3rd Edition 1998; p151 -166.

9. Oxfords textbook of clinical Nephology $-2^{\text {nd }}$ Edition.877 -893.

10. Niaudet P. Etiology, clinical manifestations, and diagnosis of Nephrotic syndrome in children. Up To Date 2013.

11. Hudsun EM, Knight JF, Willis N, et al. Corticosteroid therapy for Nephrotic syndrome in children. Cochrane data base syst. Rev .2003; CD 001533.

12. Brodehl J. Conventional therapy for idiopathic NS in children clinical Nephrol 1991, 35:S8- S15.

13. Bagga A, Hari P, Srivastava RN. Prolonged versus standard prednisolone therapy for initial episode of Nephrotic syndrome. Pediatr Nephrol. 1999; 13: 824-827.

14. Paripovic D, Kostic M, Krušcic D, et al. Indications and results of renal biopsy in children: A 10year review from a single center in Serbia. J Nephrol 2012; 25: 1054-9.

15. Ali A, Ali MU, Akhtar SZ. Histological pattern of pediatric renal diseases in northern Pakistan. J Pak Med Assoc 2011; 61:653-8.

16. Bagga A, Sharma A, Srivastava RN .Levamisole therapy in corticosteroid dependent nephritic syndrome. Pediatric Nephrol 1977: 11:415-17.

17. Haws RM, Baum M. Efficacy of albumin and diuretic therapy in children with Nephrotic syndrome. Pediatrics 1993; 91: 1142-46.

18. ISKDC Primary Nephrotic syndrome in Children Kidney Int.1981, 20765.

19. North American Pediatric Renal Trials and Collaborative Studies. NAPRTCS 2008 Annual Report: Renal Transplantation, Dialysis, Chronic Renal Insufficiency; 2008.

20. Lombel RM, Gipson DS, Hodson EM. Kidney Disease: Improving Global Outcomes. Treatment of steroid-sensitive Nephrotic syndrome: new guidelines from KDIGO. Pediatric Nephrol. 2013; 28:415-426.

21. Srivastava RN, Mayekar G, Anand R, et al. Nephrotic syndrome in Indian Children. Arch Dis Child 1975: $50-626-30$.

22. Gipson DS, Massengill SF, Yao L, Nagaraj S, Smoyer WE, Mahan JD, et al. Management of childhood onset Nephrotic syndrome. Pediatrics. 2009; 124:747-757. 


\section{ORIGINAL ARTICLE}

23. Nakanishi K, Iijima K, Ishikura K, Hataya H, Nakazato H, Sasaki S, et al. Two-year outcome of the ISKDC regimen and frequent-relapsing risk in children with idiopathic Nephrotic syndrome. Clin J Am Soc Nephrol. 2013; 8: 756-762.

24. Robbin's Basis of pathological diseases - 9th Edition $517-523$.

\section{AUTHORS:}

1. K. M. Naicker

2. V. V. Bhaskar Rao

3. K. Adi Reddy

4. Solomon Saawan P.

5. Krishna Kumari Agarwal

6. K. Veera Bhadrarao

\section{PARTICULARS OF CONTRIBUTORS:}

1. Assistant Professor, Department of Pediatrics, Rangaraya Medical College, Kakinada.

2. Assistant Professor, Department of Pediatrics, Rangaraya Medical College, Kakinada.

3. Junior Resident, Department of Pediatrics, Rangaraya Medical College, Kakinada.

4. Junior Resident, Department of ENT, Rangaraya Medical College, Kakinada.

\section{FINANCIAL OR OTHER} COMPETING INTERESTS: None
5. Junior Resident, Department of Pediatrics, Rangaraya Medical College, Kakinada.

6. Junior Resident, Department of Pediatrics, Konaseema Institute of Medical Sciences, Amalapuram.

\section{NAME ADDRESS EMAIL ID OF THE CORRESPONDING AUTHOR:}

Dr. K. Adi Reddy, Junior Resident, Department of Pediatrics, Rangaraya Medical College, Kakinada.

E-mail: adi9949844121@gmail.com

Date of Submission: 12/08/2015. Date of Peer Review: 13/08/2015. Date of Acceptance: 20/08/2015. Date of Publishing: 22/08/2015. 